\title{
Utjecaj korporativne kulture na uspješnost spajanja i preuzimanja
}

\section{The impact of corporate culture on the success of mergers and acquisitions}

\section{Sažetak}

Spajanja i preuzimanja služe kao odgovor na tehnološki razvoj, konkurenciju i ostale nepredvidljive tržišne podražaje te čine poduzeća konkurentnijima, povećavaju efikasnost, omogućuju brzi rast i stvaraju vrijednost za dioničare. Međutim, većina spajanja i preuzimanja završi neuspjehom, a mnogi odgovori za neuspjeh leže u korporativnoj kulturi. Koju su ključni izazovi integracijskih procesa, s kakvim se problemima susreću poduzeća kod spajanja i preuzimanja zbog razlika u korporativnim kulturama poduzeća te koje su moguće solucije za rješavanje navedenih problema, problematika je kojom se ovaj rad bavi.

Ključne riječi: spajanja, preuzimanja, korporativna kulture, integracijski procesi

JEL klasifikacija: F2, G3, M1

\section{Abstract}

Mergers and acquisitions serve as a response to technological development, competition and other unpredictable market stimulations. They are increasing competitiveness and efficiency of a company, as well as enabling rapid growth and creating value for shareholders. However, most mergers and acquisitions end up as a failure, and many of the reasons for failure originate from corporate culture. What are the key challenges of integration processes, what problems do companies face with mergers and acquisitions due to differences in corporate cultures and what are the possible solutions to these problems are all the issues this paper addresses.

\section{Keywords: mergers, acquisition, corporate culture, integration processes}

\section{JEL classification: F2, G3, M1}

\section{Uvod}

U današnjem poslovnom svijetu ljudski resursi nameću se kao jedan od najvažnijih i najvrjednijih resursa svake organizacije. Uspjeh svake organizacije ovisi o znanju, vještinama i sposobnostima njenih zaposlenika. Uočavanjem doprinosa i značaja ljudskog faktora za postizanje konkurentske prednosti, a posljedično i dobrih poslovnih rezultata, organizacijska ili korporativna se kultura postavlja kao jedan od najznačajnijih varijabli menadžmenta.
Spajanja i preuzimanja jedan su od načina provedbe razvojne strategije poduzeća. Naime, spajanja i preuzimanja omogućuju poduzećima rast u veličini organizacije, poduzeća održavaju konkurentnima, stvaraju vrijednost za dioničare te pospješuju efikasnost. Uspješnost spajanja i preuzimanja ovisi o različitim faktorima, a jedan od najvažnijih, ali često i zanemaren faktor, je korporativna kultura. Korporativna kultura predstavlja način rada, ponašanja i komuniciranja u nekom poduzeću. Svako poduzeće potiče i usmjerava zaposlenike na određen oblik ponašanja i suradnje. Korporativna
Doc.dr.sc.Zoran Wittine

Ekonomski fakultet Sveučilišta u Zagrebu E-mail: zwittine@efzg.hr

Helena Bedeković, mag. oec.

Philip Morris Zagreb d.o.o.

E-mail:helena.bedekovic@gmail.com

\section{Izv. prof. dr. sc. Davor Filipović}

Ekonomski fakultet Sveučilišta u Zagrebu E-mail:dfilipovic@efzg.hr

Asst. prof. Zoran Wittine, PhD Faculty of Economics and Business, University of Zagreb

E-mail: zwittine@efzg.hr

\section{Helena Bedeković, MSC}

Philip Morris Zagreb Itd

E-mail:helena.bedekovic@gmail.com

Assoc. prof. Davor Filipović, PhD

Faculty of Economics and Business,

University of Zagreb

E-mail:dfilipovic@efzg.hr 
Wittine, Z., Bedeković, H., Filipović, D.

Utjecaj korporativne kulture na uspješnost spajanja i preuzimanja je kultura, bez sumnje, kritični faktor za uspjeh u današnjoj internacionalnoj poslovnoj okolini i utječe na poslovanje poduzeća u svakoj njegovoj fazi. Na koji način korporativna kultura utječe na uspješnost spajanja i preuzimanja, pitanje je kojim se ovaj rad bavi.

Slijedom navedenog u radu će se izložiti teorijski pregled ključnih pojmova, odnosno pojmova vezanih uz spajanje i preuzimanje te korporativnu kulturu, objasniti će se ključni izazovi s kojima se susreću poduzeća pri spajanjima i preuzimanjima,te će se rašclaniti glavni uzroci neuspjeha navedenih integracijskih procesa kako bi se naposljetku analiziralo na koji način korporativna kultura može utjecati na uspješnost provedbe integracijskih procesa, odnosno spajanja i preuzimanja. Analiza je provedena na temelju dostupnih sekundarnih podataka odnosno metodom sinteze najznačajnije recentne literature.

\section{Korporativna kultura}

Peters i Waterman (1972.) bili su prvi koji su naglasili važnost korporativne kulture gdje su jaku kulturu istaknuli kao jednu od 8 karakteristika uspješnih poduzeća. Korporativna kultura složen je pojam, a ovisno o pristupu i aspektima promatranja korporativne kulture javlja se velik broj definicija iste.

Korporativna ili organizacijska kultura predstavlja sustav svih zajedničkih pretpostavki i značenja, odnosno niz vrijednosti, normi i uvjerenja koji u velikoj mjeri određuju na koji način će se ljudi u organizaciji ponašati (Mallak, 2001.).

Kultura je način života i rada u poduzeću. Ona je sistem vrijednosti, uvjerenja, običaja unutar neke organizacije, koji su u interakciji s formalnom strukturom proizvodeći norme ponašanja. Predstavlja osobnost odnosno karakter poduzeća (Sikavica i Novak, 1993.).

Organizacijska kultura je postupak donošenja odluka i rješavanje problema procesa organizacije. Ona utječe na ciljeve, novčana sredstva i vrstu akcije. Izvor je motivacije, zadovoljstva i nezadovoljstva (Walters, Dobson i Williams, 1993.).

Korporativna kultura predstavlja obrazac vrijednosti ili temeljnih pretpostavki kojeg je izumila, otkrila ili razvila određena grupa dok je učila suočavati se s problemima vanjske prilagodbe i unutrašnje integracije, a koji se pokazao dovoljno dobrim da je smatran valjanim, pa stoga tom obrascu treba poučiti nove članove kao ispravnom načinu percipiranja, mišljenja i osjećanja u odnosu na te probleme (Schein, 2004.).

Organizacijska kultura je skupina čimbenika koji određuju (konstruiraju) zajednički identitet svih ljudi koji pripadaju određenoj organizaciji. Osim definiranja pripadnosti, kultura omogućava lakše suočavanje s neizvjesnošću, stvara poredak u društvenim sustavima i olakšava stvaranje i održavanje organizacije (Pavičić, Alfirević i Aleksić, 2006.).

Poznavanjem sastavnica korporativne kulture, olakšava se njeno razumijevanje.Prema Armstrongu postoje tri važne sastavnice korporativne kulture, a to su organizacijske vrijednosti, organizacijska klima i menadžerski stil (Žugaj i Cingula, 1992.).

Organizacijske vrijednosti su relativno stabilne, trajne i osnovne koncepcije onoga što poduzeće želi postići te predstavljaju svojevrsnu operacionalizaciju strategije. One predstavljaju okvir i osnovni vodič za ponašanje. Osnovne vrijednosti, kao što su kvaliteta, pouzdanost i uslužnost predstavljaju bitan element uspješnih poduzeća. Njihovo pridržavanje na individualnoj razini je pretpostavka opstanka u organizaciji, nagrađivanja, statusa i dr., dok je na organizacijskoj razini pretpostavka uspješne realizacije strategije.

Organizacijska klima može se definirati kao način percepcije svega što se događa u organizaciji, tj. kako pojedinci percipiraju organizaciju. Drugim riječima, ona je radna atmosfera koja je izražena iskustvom zaposlenih, njihovim shvaćanjima, međusobnim odnosima te odnosom prema kvaliteti organizacijskih vrijednosti. Ona ima značajnu ulogu u oblikovanju ponašanja i zadovoljstva zaposlenika i utječe na njihove stavove o upravljanju znanjem. Klima ima utjecaj i na motivaciju, predanost, kreativnost i inovacije. Jedan od načina kako poduzeća mogu održati konkurentsku prednost je da stalno potiču inovativnu atmosferu koja ce postati dio internih procesa, procedura i sposobnosti poduzeća.

Menadžerski stil predstavlja način na koji se menadžeri ponašaju u poduzeću. Menadžerskih 
stilova ima mnogo, a kreću se u rasponu između dva stila: autokratskog i demokratskog. Autokratski stil vodstva karakterizira nepovjerenje menadžmenta u podređene te donošenje odluka samo na vrhu bez konzultiranja $s$ zaposlenicima, odnosno komunikacija je samo prema dolje. Autokratskom vođi su važniji uspjeh i profit poduzeća nego ljudi. Za razliku od autokratskog, demokratski stil okarakteriziran je povjerenjem menadžmenta u svoje podređene, prijateljskim odnosom između nadređenih i podređenih te donošenjem odluka na svim razinama u poduzeću, stoga je komunikacija prisutna u svim smjerovima. U takvim organizacijama prisutna je velika briga za ljude.

Korporativnu kulturu čine vrijednosti, norme, simboli, običaji i rituali, jezik i komunikacija te stavovi i uvjerenja (Bahtijarević-Šiber i sur., 1991.). Vrijednosti, norme, stavovi i uvjerenja spadaju u nevidljive znakove kulture. Oni predstavljaju srž organizacijske kulture, a prenose se na članove socijalizacijom, putem priča, običaja, rituala i simbola (Galetić, 2011.).

Nakon utvrđivanja sastavnica korporativne kulture, također je bitno ukazati sve funkcije koje kultura ima u poduzeću. Funkcije korporativne kulture su sljedeće: ona utječe na ukupnu uspješnost i razvoj poduzeća, te usmjerava odluke i ponašanje pojedinaca, temeljni je i najdjelotvorniji način ostvarenja strategije, na osnovi organizacijske kulture vizija organizacijskog razvoja postaje transparentna i zajednička svim djelatnicima organizacije, zamjenjuje formalnu strukturu odnosno eliminira pravila i propise, predstavlja mehanizam po kojem se poduzeće prilagođava svojoj okolini, daje zajednički obrazac ponašanja radnika u organizaciji, usmjerava ljudske potencijale za postizanje specifičnih misija i ciljeva poduzeća, te učvršćuje socijalne odnose određuje kako nas vidi okolina, kupci, poslovno partneri, konkurencija i šira javnost, integrira različite podsustave organizacije i društva, organizacijske te individualne ciljeve, temeljni je izvor svrhe i stabilnosti organizacije, te osigurava kontinuitet i autonomiju djelovanja pojedinca (Žugaj, 2004.).

Prema Smircich (1983.) organizacijska kultura ima četiri osnovne funkcije, a to su davanje članovima organizacije osjećaj identiteta odnosno pripadnosti poduzeću, postizanje odanosti poduzeću od strane zaposlenih, stvaranje stabilnosti u poduzeću kao socijalnom sustavu te strukturiranje zaposlenih dajući im tako na znanje u kakvoj se okolini nalaze (Smircich, 1983.).

\section{Integracijski procesi - spajanja i preuzimanja}

Kako bi se razumio način na koji se spajanja i preuzimanja događaju te na koji se način odvija interakcija s korporativnom kulturom poduzeća, bitno je razumjeti osnovne pojmove i koncept spajanja i preuzimanja.

Na prvi pogled, razlika u značenju ova dva pojma možda se čini neznačajna, budući da je često neto rezultat oba procesa jednak: dva (ili više) poduzeća koja su imala odvojeno vlasništvo, sada rade pod istim vlasništvom, obično kako bi ostvarili neki strateški ili financijski cilj (Sherman, 2010.). Međutim, spajanja i preuzimanja moraju se promatrati kao dva odvojena izraza, jer su oba različita u značenju (Rana, Jayasooriya i Nikolova, 2010.).

Spajanje ili fuzija (eng. merger) predstavlja udruživanje dvaju ili više poduzeća. Prilikom spajanja dvaju ili više poduzeća nastaje novo poduzeće, a prije samostalna poduzeća prestaju postojati (Filipović, 2012.). Najčešće se spajaju dotadašnji konkurenti na tržištu u istoj grani industrije, a i obično se odvija između dva poduzeća podjednake veličine (Rana, Jayasooriya i Nikolova, 2010.). Drugim riječima, spajanje podrazumijeva kada se dva ili više pravnih subjekata spoje u novi, a da se pri tome ne provodi likvidacija tih društava, nego cjelokupna njihova imovina i obveze prelaze u novonastali pravni subjekt (Škuflić i Šokčević, 2016.). Spajanja uvijek karakterizira dobrovoljnost svih sudionika takvog postupka, a najčešće se financiraju zamjenom dionica. Omjeri zamjene ovise o tržišnim cijenama oba poduzeća. Ime novonastalog poslovnog subjekta najčešće uključuje oba imena do tada samostalnih kompanija (Filipović, 2012.)

0 pripajanju jednog ili više dioničkih društava nekom drugom dioničkom društvu govori se kada dioničko društvo ili više njih prenesu svu svoju imovinu (imovinu pripojenih društava) drugome društvu (društvu preuzimatelju). U takvoj situaciji društvo koje se pripaja prestaje samostalno
Wittine, Z., Bedeković, H., Filipović, D.

Utjecaj korporativne kulture na uspješnost spajanja i preuzimanja 
Wittine, Z., Bedeković, H., Filipović, D.

Utjecaj korporativne kulture na uspješnost spajanja i preuzimanja poslovati (Filipović, 2012.), odnosno nastavlja svoje poslovanje unutar poduzeća kojem se pripojio. Ovim činom dolazi i do vlasničkih transformacija poduzeća preuzimatelja i pripojenog mu poduzeća. Nakon pripajanja, poduzeće koje je pripojeno gubi pravnu osobnost dok je poduzeće preuzimatelj ne gubi, ali kod njega dolazi do vlasničke i organizacijske promjene (Škuflić i Šokčević, 2016.).

Preuzimanje (eng. acquisition) se događa kada jedno poduzeće preuzme kontrolu nad drugim poduzećem. Dakle, preuzimatelj dobiva kontrolu nad poslovanjem i imovinom ili dionicama poduzeća-mete. Preuzimanje obično uključuje jedno poduzeće - kupca - koje kupuje imovinu ili dionice prodavatelja, s tim da su oblik plaćanja gotovina, vrijednosni papiri kupca ili nešto treće u čemu prodavatelj vidi vrijednost (Sherman, 2010.). Preuzeto poduzeće postaje sastavni dio veće i tržišno jače kompanije, a može se dogoditi da uzme i njeno ime. Ponekad preuzeto poduzeće zadržava i vlastito ime poslujući unutar nove grupe, ali gubi poslovnu samostalnost na način da umjesto svoje dotadašnje strategije provodi strategiju poduzeća koje ga je preuzelo (Filipović, 2012.).

Prijateljsko preuzimanje je ono preuzimanje u kojem se menadžment poduzeća-mete ne protivi preuzimanju i smatra da je preuzimanje dobar izbor za sve vlasnike poduzeća. $U$ toj situaciji menadžment poduzeća-mete, nakon dogovora 0 prodaji dionica $s$ preuzimateljem, obavještava vlasnike o prodaji te im preporuča da svoje dionice proda preuzimatelju (Filipović, 2012.).

Od preuzimatelja se očekuje da dioničarima poduzeća-mete ponudi veću cijenu za dionice od one tržišne. Visak ponuđene cijene u odnosu na cijenu dionice prije preuzimanja naziva se premija za preuzimanje ili akvizicijska premija (Filipović, 2012.). Preuzimatelj kupnju dionica poduzećamete obično obavlja putem javne ponude, gdje s dioničarima poduzeća-mete najčešće komunicira putem sredstava javnog priopćavanja.

Neprijateljsko preuzimanje događa se kada menadžment poduzeća-mete odbija ponudu, a preuzimatelj i dalje nastoji preuzeti poduzeće-metu ili kada preuzimatelj daje ponudu dioničarima bez prethodnog informiranja menadžmenta poduzećamete. Dakle, pri neprijateljskom preuzimanje ne postoji dogovor između menadžmenta poduzeća- mete i preuzimatelja.

U slučaju neprijateljskog preuzimanja menadžment poduzeća mete obično biva smijenjen, za razliku od prijateljskog kada menadžment preuzetog poduzeća u velikom broju slučajeva zadržava poziciju koju je imao prije preuzimanja (Tipurić, 2008.). Neprijateljska preuzimanja često su zaključena po mnogo višoj cijeni od prijateljskih zato što mogu privući i druge kupce koji prvobitno nisu bili zainteresirani za poduzeće-metu. Takva preuzimanja utječu na samopouzdanje zaposlenika ciljane kompanije, što vrlo brzo može dovesti do ogorčenosti naspram kompanije koja „napada”. Iz tog razloga, ali i zbog činjenice da je integracija poduzeća-mete u poslovni sustav preuzimatelja puno brža, akteri preuzimanja teže preuzimanjima koja imaju prijateljski karakter (DePamphilis, 2010.).

\section{Izazovi u procesima spajanja i preuzimanja}

Poduzeća se tijekom spajanja i preuzimanja susreću s brojnim izazovima koji su grupirani u četiri skupine, a to su integracijski izazovi, menadžerski izazovi, te izazovi povezani s procjenom vrijednosti poduzeća-mete is realizacijom sinergije.

\subsection{Integracijski izazovi}

Proces integracije odnosi se na proces nakon zaključenja sporazuma o spajanju i preuzimanju, kada bi kombinirano poduzeće trebalo surađivati i raditi kao jedno poduzeće. Integracija se može podijeliti na dvije razine, a to su integracija zadataka i ljudska integracija. Integracija zadataka fokusirana je na povezivanje različitih financijskih i kontrolnih sustava, dok se ljudska integracija fokusira na izgradnju učinkovitih radnih odnosa, menadžerske integracije, zadovoljstva radnika i integracije u korporativnoj kulturi poduzeća

Integracija zadataka nakon spajanja ili preuzimanja iziskuje poteškoće jer se sustav dva različita poduzeća treba spojiti i funkcionirati kao cjelina. Postoji mogućnost da poduzeća koristite različite sustave koji ne mogu raditi lako zajedno. Stoga je potrebno da se jedan sustav zamijeni kako bi integracija djelovala. Pored toga, funkcije koje se preklapaju trebale bi biti uklonjene, dok bi se tehnologija, sposobnosti i intelektualni kapital trebali povećati nakon integracije (Houwers, 2016.). 
Ljudska integracija naglašava ljudsko zadovoljstvo u oba poduzeća i stvaranje atmosfere međusobnog poštovanja i povjerenja. Kada se spajaju dva poduzeća, novonastalo poduzeće može se sastojati od dvije različite korporativne kulture, različitih stavova menadžmenta i nezadovoljnih zaposlenika što posljedično može stvoriti napetost u novonastalom poduzeću i naštetiti vrijednosti poduzeća. Naglasak bi trebao biti istovremeno na integraciji zadataka i na ljudskoj integraciji. Kad su zaposlenici zadovoljni, prijenos vještina i razmjena resursa bit će lakši nego kad su oni nezadovoljni. Istovremeno, integracija zadataka će vjerojatno potaknuti zadovoljstvo radnika. Ako se integracija zadatka i ljudska integracija razlikuju, to može negativno utjecati na vrijednost spajanja i preuzimanja. Primjerice, ako se integracija zadataka postiže na štetu ljudske integracije, to će rezultirati nemotiviranim zaposlenicima koji nisu predani organizaciji. Nemotivirani zaposlenici, čak i ako ne daju ostavke, štete vrijednosti poduzeća (Houwers, 2016.).

Također, dokazano je da slaba sociokulturna integracija ograničava učinkovitost integracije zadataka kao pokretača operativnih sinergija. Drugim riječima, slaba sociokulturna integracija blokirat će uspješnu integraciju zadataka, koja ne može biti ostvarena brže od uspješne ljudske integracije (Stahl, Günter i Voigt, 2008.).

Porastom različitosti u korporativnim kulturama raste vjerojatnost da su takva poduzeća nekompatibilna za proces spajanja i preuzimanja te će se poduzeća, ukoliko dođe do spajanja i preuzimanja, susresti $s$ implementacijskim problemima, što će narušiti uspješan prijenos vještina te dijeljenje resursa i učenja (Appelbaum, 2007.).

\subsection{Menadžerski izazovi}

Menadžerski izazovi odnose se na izazove s kojima se susreću menadžeri kada se suočavaju sa spajanjem ili preuzimanjem. Te poteškoće uključuju motive menadžera za ulazak u proces spajanja i preuzimanja, vrijeme koje zahtijevaju integracijski procesi, ali i razlike u korporativnim kulturama poduzeća (Marks i Howard, 2015.).

Ako je jedina namjera spajanja i preuzimanja stvoriti rast, dioničari neće imati koristi od integracijskih procesa jer ova namjera ima više veze sa traženjem slave menadžera nego s poslovnom strategijom. Ovakve integracije mogu biti vođene strahom. Novi tehnološki razvoj, sve veća konkurencija, globalizacija ili gospodarstvo koja se brzo mijenja, mogući su čimbenici koji potiču spajanje i preuzimanje iz straha (Houwers, 2016.). Izazov za menadžere jest osigurati da se slijedi ispravan motiv za spajanje i preuzimanje.

Spajanja i preuzimanja zahtijevaju da viši menadžment skrene pažnju sa svakodnevnih poslova i usredotoči se na nešto što je vjerojatno najveći izazov s kojim se njihova organizacija susreće. Bez obzira na to je li menadžment to shvatio ili ne, bilo koja organizacija koja je uključena u spajanje ili preuzimanje je u najranjivijem stanju. Spajanje ili preuzimanje donosi izazov vođenja poslovanja poduzeća preuzimatelja, dok se istovremeno mora upravljati procesom spajanja i preuzimanja (Appelbaum, 2007.). Menadžeri moraju biti intenzivno uključeni tijekom pregovaračke faze preuzimanja (Nguyen i Kleiner, 2003.). Čak i kad je ugovor zaključen, menadžeri bi trebali ostati usredotočeni na transakciju. Samim time nameće se izazov za upravljanje vremenom (Houwers, 2016.). Također, menadžment je odgovoran da se ljudska integracija odvija glatko (Nguyen i Kleiner, 2003.).

Nadalje, postoji vremenski pritisak u vezi s "brzim startom". Otprilike, prva tri mjeseca nakon transakcije ključna su kako bi promjena bila uspješna. Menadžeri bi trebali biti svjesni toga te trebaju izdvojiti vrijeme da se usredotoče na dobar početak novonastalog poduzeća (DiGeorgio, 2002). Vrijeme koje je potrebno za ljudsku integraciju i dobar početak ne treba podcjenjivati i menadžmentu predstavlja izazov (Nguyen i Kleiner, 2003.).

Osim toga, kad se kulture poduzeća značajno razlikuju, menadžmentu to predstavlja dodatni izazov Menadžment ne samo da mora imati posla s razlikama u upravljanju s menadžmentom ciljanog poduzeća, već mora pokušati usmjeriti ili zadržati zaposlenike. Zaposlenici poduzeća-mete mogli bi se osjećati napadnuto zbog preuzimanja. Menadžment je odgovoran za stvaranje povoljnog radnog okruženja u kojem se zaposlenici više neće osjećati napadnuto i gdje će biti predani poduzeću. Pored toga, ako su, primjerice,zaposlenici poduzećamete naviknuti na vrlo otvorenu kulturu poduzeća
Wittine, Z., Bedeković, H., Filipović, D.

Utjecaj korporativne kulture na uspješnost spajanja i preuzimanja 
Wittine, Z., Bedeković, H., Filipović, D.

Utjecaj korporativne kulture na uspješnost spajanja i preuzimanja u kojoj je lak pristup visokom menadžmentu i gdje je fleksibilno radno vrijeme normalno, menadžment preuzimatelja bi trebao biti oprezan u nagloj promjeni navedenih stavki (Houwers, 2016.).

\subsection{Procjena vrijednosti poduzeća-mete}

Određivanje prave cijene ciljanog poduzeća još je jedan izazov s kojim se susreće poduzeće preuzimatelj. Obično je cijena koja se plaća za kupnju poduzeća-mete veća od njene intrinzične vrijednosti. Premija se plaća za npr. očekivanu sinergiju. Izazovi procjene vrijednosti ciljanog poduzeća uključuju izbor metode procjene vrijednosti, asimetriju informacija između kupca i prodavatelja te procjenu vrijednosti imovine.

Dakle, kako bi se utvrdila cijena ciljanog poduzeća, koriste se različite metode procjene vrijednosti. (Houwers, 2016.). Međutim, ne postoji samo jedna metoda koja je najprikladnija za svaku situaciju. Koja će se tehnika procjene vrijednosti koristiti ne ovisi samo o industrijskom sektoru poduzeća, već i o njenim karakteristikama, ali i preferencijama analitičara (Petit i Ferris, 2013.).

Nadalje, asimetrija informacija između preuzimatelja i poduzeća-mete može otežati procjenu vrijednosti ciljanog poduzeća. Asimetrija informacija nastaje kada jedna strana u transakciji ima pristup više informacija ili superiornijim informacijama od druge strane (Houwers, 2016.). Kada preuzimatelj posumnja da ciljano poduzeće nije podijelilo sve dostupne podatke, preuzimatelj shvaća da bi vrijednost ciljanog poduzeća trebala biti niža od cijene koja je prvotno predložena. To pokazuje kako asimetrija informacija može utjecati na cijenu ciljanog poduzeća. Relativno mlada poduzeća češće su primijetila informacijsku asimetriju od starijih dobrostojećih poduzeća. (Pablo i Javidan, 2009.).

Također, javlja se izazov određivanja cijene nematerijalne imovine (Pablo i Javidan, 2009.). Budući da nematerijalna imovina predstavlja bitan dio poslovanja u trenutnom poslovnom svijetu, javljaju se poteškoće kod kvantificiranja ekonomske i monetarne vrijednosti iste. Uz to, treba napomenuti da je nematerijalna imovina povezana $s$ više nesigurnosti u odnosu na materijalnu imovinu. Navedena nesigurnost povezana je $s$ iznosom i vremenskim rokom budućih ekonomskih koristi nematerijalne imovine. Nedostatak fizičke opipljivosti, višestruki pristupi procjeni vrijednosti nematerijalne imovine i povezana neizvjesnost otežavaju utvrđivanje vrijednosti nematerijalne imovine i stoga nameću izazov u vezi s procjenom vrijednosti ciljanog poduzeća (Houwers, 2016.).

\subsection{Realizacija sinergije}

Postizanje očekivane sinergije nakon spajanja i preuzimanja od suštinskog je značaja jer su sinergije ključni racionalni razlog za ulazak u integracijske procese. Sinergija novonastalom poduzeću dodaje vrijednost koja kombinirano poduzeće čini vrijednim od njihovih pojedinačnih vrijednosti. Izazovi u realizaciji predviđenih sinergija preklapaju se s ranije raspravljenim izazovima, a kreću se od procjene ukupnih dostupnih sinergija, poteškoća u integraciji, do očekivanih troškova i potrebnog vremena za ostvarenje sinergije. Da bi se realizirale predviđene sinergije, prvo se mora napraviti procjena predviđenih sinergija. Kad je procjena predviđenih sinergija pogrešna, bit će teže postići očekivane sinergije. Izazov određivanja ispravne cijene ciljanog poduzeća preklapa se s izazovom procjene sinergije. Kad se mora procijeniti ispravna cijena ciljanog poduzeća, vrijednost očekivanih izazova bit će ugrađena u cijenu. Stoga su izazovi u pogledu određivanja cijene usporedivi s izazovom procjene sinergije (Houwers, 2016.).

Izravniji izazov u pogledu realizacije predviđenih sinergija dolazi s izazovima integracije zadatka i ljudske integracije. Integracija zadataka i ljudska integracija preduvjet su za ostvarenje sinergija (Houwers, 2016.). Ako u novonastaloj organizaciji nedostaje pozitivan stav i zadovoljni zaposlenici, manje je vjerojatno da će se ostvariti sinergije (Uzelac, 2015). Kad ljudska integracija nije uspjela, unutar organizacije može postojati negativna atmosfera i razlike u korporativnoj kulturi. Kulturne razlike mogu utjecati na stupanj realizacije sinergija. To ukazuje na vezu između integracijskih izazova i izazova realizacije predviđenih sinergija.

Kulturne razlike utječu na to kako i u kojoj se mjeri sinergije realiziraju, a to je moguće pružanjem pristupa jedinstvenim i potencijalno vrijednim sposobnostima, resursima i mogućnosti učenja pri različitom kulturnom okruženju (Stahl, Günter i Voigt, 2008.). 
Slika 1. Međupovezanost između izazova u procesima spajanja i preuzimanja i funkcija organizacijske kulture

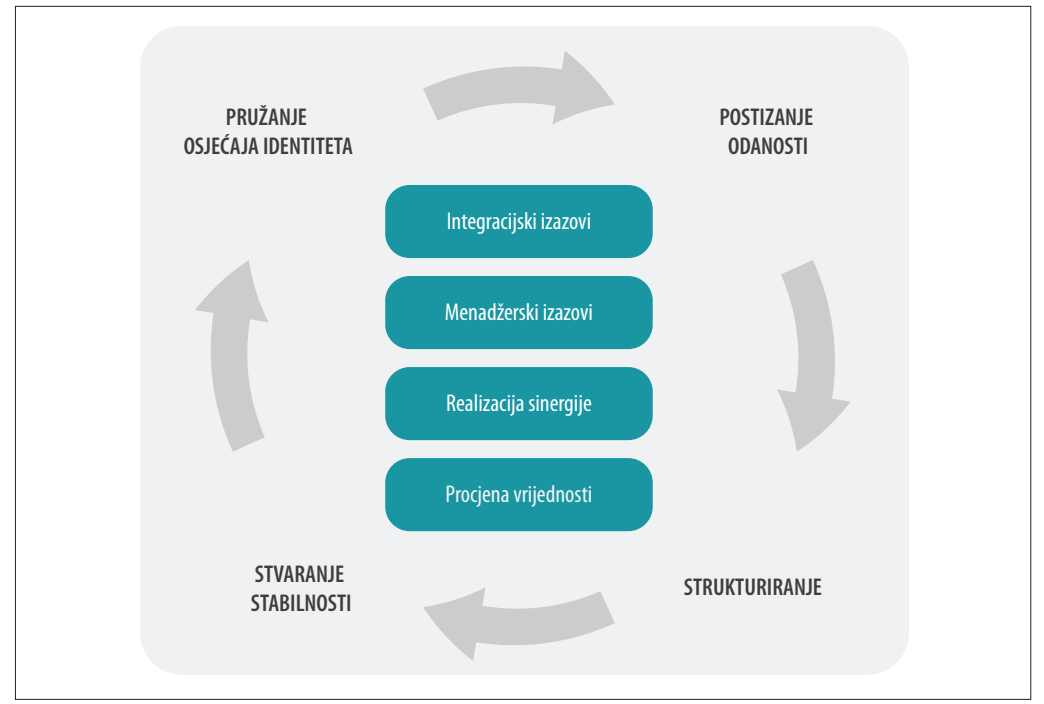

Izvor: izrada autora.

Razlike u korporativnoj kulturi utječu na stvaranje sinergije povećanjem kombiniranog potencijala nakon spajanja i preuzimanja. Sinergijska komplementarnost može uključivati različite proizvode, know-how za istraživanje i razvoj, pristup tržištu ili upravljačke sinergije. Međutim, kombinacijski potencijal ne znači automatski sinergijsku korist. Mnoga istraživanja ukazuju na ograničenja u procesu sinergijske realizacije, sugerirajući da je provođenje dobro osmišljenog procesa integracije koji umanjuje interorganizacijsko i interkulturalno trenje od presudnog je značaja za postizanje predviđenih sinergija (Stahl, Günter i Voigt, 2008.).

Nadalje, troškovi i vrijeme potrebno za postizanje sinergije često se podcjenjuju. Kada se podcijene troškovi i vrijeme, bit će teže realizirati očekivane sinergije. Uz to, ključna je napredna priprema kako bi se sinergije što prije realizirale. Ako je, primjerice, preuzimatelj u stanju brzo apsorbirati nove proizvode i staviti in na tržište prije nego što konkurent može učiniti nešto slično, napredna priprema može biti presudna za konkurentski položaj. Ljudski resursi mogu pridonijeti i u ovoj fazi zadržavanjem ključnih talenta u poduzeću te održavanjem produktivnosti (Price, 2013.) Za procjenu vremena i troškova potrebnih za realizaciju sinergije potrebni su ključni zaposlenici poduzeća. Kada se podcijene troškovi, ukupna dodana vrijednost kroz sinergije bit će manja od očekivane. Kad se vrijeme podcijeni, sinergije će se realizirati kasnije nego što se očekuje i na taj način će se sniziti ukupnu vrijednost sinergija.

Ukratko, samo integracija zadataka i ljudska integracija neće biti dovoljni za realizaciju potencijalnih sinergija. Potrebno je prevladati kombinaciju izazova u korist postizanja potencijalnih sinergija. Navedeni izazovi nisu neovisni jedan o drugome. Na primjer, realizacija sinergija dijelom ovisi o postignutom stupnju integracije. Drugi je primjer, ako menadžment nije sposoban upravljati razlikama u kulturi poduzeća (što predstavlja izazov menadžmenta), to će imati negativan učinak na ljudsku integraciju. Sve navedeno ukazuje da su izazovi međusobno povezani i preklapaju se jedan s drugim (Houwers, 2016.).
Wittine, Z., Bedeković, H., Filipović, D.

Utjecaj korporativne kulture na uspješnost spajanja i preuzimanja 
Wittine, Z., Bedeković, H., Filipović, D.

Utjecaj korporativne kulture na uspješnost spajanja i preuzimanja

\section{Uzroci neuspjeha spajanja i preuzimanja}

Cilj spajanja i preuzimanja je poduzeću omogućiti da iskoristi sinergije, poveća tržišni udio, poboljša intelektualno vlasništvo i talent unutar nove organizacije. Međutim, provođenjem pregleda uspješnosti novih organizacija utvrđeno je da prošlost spajanja i preuzimanja nije sjajna. Naime, unatoč navedenim ciljevima, pokazalo se da od $40 \%$ do $80 \%$ spajanja i preuzimanja ne ispunjavaju navedena očekivanja. Time se postavlja pitanje koji faktori utječu na uspješnu realizaciju ciljeva spajanja i preuzimanja, i posebno, kakva je uloga organizacije i njene kulture u ostvarivanju uspjeha ili neuspjeha integracijskih procesa (Dunbar, 2014.).

Uzroci neuspjeha svrstani su u četiri skupine, a to su ljudski faktor, problemi s evaluacijom, problemi s menadžmentom te integracijski problemi.

\subsection{Ljudski faktor}

Ova se kategorija proseže od slabe kulturalne podudarnosti, otpora zaposlenika, pa sve do psiholoških pitanja i problema. Ukratko, svaki faktor neuspjeha koji je povezan s nedovoljnim rješavanjem ljudskih aspekata tijekom ili nakon spajanja i preuzimanja, može se svrstati u ovu kategoriju.

Ljudska integracija je ključna za postizanje potencijalnih sinergija jer izravno utječe na rezultate zaposlenika (Gunkel, 2014.). Otpor zaposlenih, kao faktor neuspjeha koji je uključen u ovu kategoriju, također je dio ljudske integracije. Isti argumenti odnose se na nezadovoljstvo radnika i kupaca. Kad su zaposlenici nezadovoljni, to može dovesti do otpora zaposlenika, pa tako i do slabe ljudske integracije. Kada su kupci nezadovoljni, to dovodi do pada profitabilnosti, a pad profitabilnosti negativno utječe na ukupni ishod spajanja i preuzimanja (Houwers, 2016.).

Spajanja i preuzimanja imaju snažan utjecaj na zaposlenike, posebno ako rezultiraju porastom stresa i tjeskobe zbog promjena u radnoj praksi i zadacima, upravljačkoj rutini, okruženju kolega, hijerarhiji, itd. Spajanja i preuzimanja često uvode klimu neizvjesnosti među zaposlenicima zbog mogućnosti gubitka posla i mogućnosti zastoja budućeg razvoja karijere. Stres i nesigurnost mogu dovesti do otpora zaposlenika prema promjenama, velikog broja odlaska zaposlenika, izostanaka s posla i nedostatka predanosti radu i organizaciji, što je zauzvrat povezano s negativnim utjecajem na uspjeh spajanja i preuzimanja (Mirc, 2007.). Pojedinci nerijetko imaju selektivnu percepciju o promjenama što vodi pristranim razmišljanjima koja se razlikuju od realnosti i rezultiraju otporom (Filipović, 2012.). Otpor zaposlenika sprječava izgradnju funkcionirajuće organizacije i konstruktivnog kooperativnog okruženja. Visok broj odlazaka zaposlenika donosi značajne gubitke znanja za poduzeće. Nedostatak i manja predanost radu imaju negativan utjecaj na pojedinačne i organizacijske performanse mjerene u smislu produktivnosti, kvalitete i usluge. $S$ druge strane, smatra se da zadovoljni zaposlenici rade više, kvalitetnije i duže $s$ većom evidencijom produktivnosti (Mirc, 2007.). Iznimno je važno da menadžment poduzeća zaposlenicima kaže što će novonastala organizacija značiti za njih te da in upozna s promjenama koje su se dogodile ili koje će se dogoditi (Appelbaum, 2007.).

Nužno je u procesu planiranja spajanja i preuzimanja znati sljedeće stvari, a to je da zaposlenici ne vole promjene i razumiju in kao prijetnju, da pravila i postupci koji u jednom poduzeću dobro funkcioniraju, ne moraju nužno raditi u drugom poduzeću, da komunikacija treba biti usmjerena na dijalog, a ne na monolog, da konačna kultura treba odražavati temeljne vrijednosti oba poduzeća, da je potrebno razumjeti okruženje poduzeća koje određuje korporativnu kulturu, te je potrebno nanovo formulirati ulogu pojedinih organizacijskih jedinica i dijalogom postići usklađenost u percepciji nove odgovornosti i uloge (Kazik, 2012.).Ukoliko se navedeni čimbenici percipiraju na vrijeme, ljudski se faktor kao uzrok neuspjeha smanjuje.

Drugi faktor neuspjeha u ovoj kategoriji su nekompatibilni stilovi upravljanja. Navedeno se odnosi na različite stilove upravljanja dvaju poduzeća koja sudjeluju u integracijskom procesu. Menadžerski stilovi moraju biti dobro integrirani, što in čini dijelom procesa ljudske integracije. Nespojivi menadžerski stilovi mogu dovesti do stresa, problema s implementacijom i slabijih performansi oba poduzeća (Houwers, 2016.). 


\subsection{Problemi s evaluacijom}

Ova kategorija obuhvaća sve faktore neuspjeha koji pripadaju problemima $s$ procjenom vrijednosti poduzeća. Primjeri faktora neuspjeha koji uključuju ovu kategoriju su pogrešno procjenjivanje vrijednosti ciljanog poduzeća, problemi s metodama vrednovanja i precjenjivanje sinergijskog potencijala (Houwers, 2016.).

Problemi s procjenom vrijednosti ciljanog poduzeća mogu dovesti do neuspjeha jer često rezultat pogrešne procjene dovodi do plaćanja neprimjerene cijene. Kad se za cilj plati neprimjerena cijena, biti će teže postići željeni rezultat preuzimanja. Premija za ciljano poduzeće dijelom se temelji na očekivanim sinergijama proizašlim iz spajanja i preuzimanja (Shusta, 1999.). Stoga, kada poduzeće preuzimatelj plati previsoku premiju za ciljano poduzeće, onda se za poduzeće-metu plaća neprimjerena cijena te je prema tome, manje moguće ostvariti profitabilne prihode (Houwers, 2016.).

Drugi faktor neuspjeha u ovoj kategoriji je poremećen protok informacija, odnosno asimetrija informacija. Kao što je već spomenuto u prijašnjem poglavlju, asimetrija informacija može povećati razinu teškoće pri vrednovanju ciljanog poduzeća. U slučaju poremećaja protoka informacija, preuzimatelj osjeća da ciljano poduzeće nije podijelilo sve relevantne podatke. Stoga je teže procijeniti pravu vrijednost ciljanog poduzeća.

\subsection{Problemi s menadžmentom}

Ova je kategorija najšira kategorija od svih i uključuje najviše pojedinačnih faktora neuspjeha. Primjeri faktora neuspjeha uključuju loše kompetencije menadžmenta, pogrešne namjere stjecanja i podcjenjivanje vremena i troškova radi postizanja sinergije (Houwers, 2016.).

Nedostatak iskustva menadžerskog tima preuzimatelja u procesu spajanja i preuzimanja i činjenica da je svako spajanje i preuzimanje jedinstveno mogu objasniti razloge za neuspjeh. Upravljanje pozitivnim i negativnim implikacijama procesa integracije, tj. maksimiziranje ekonomičnosti troškova i povećanja prihoda uz minimiziranje organizacijskih poremećaja, zahtijeva menadžersku improvizaciju, ali i iskustvo. Integracijski su procesi, u stvari, povezani s višom razinom iskustava u procesima spajanja i preuzimanja i razvojem menadžerskih alata za podršku upravljanja potrebnim za proces integracije (Appelbaum, 2007.).

Problem nastaje kada menadžeri ne raspodijele dobro svoje vrijeme na upravljanje poduzećem preuzimatelja i fokusiranost na proces spajanja i preuzimanja. Pored toga, kada se dva poduzeća spajaju ili kada dolazi do preuzimanja, tada se dešava promjena koja zahtjeva odgovarajuće postupanje $s$ istom. Kada uprava nije dovoljno kompetentna da na ispravan način rješava izazovne promjene, spajanje ili preuzimanje može propasti (Houwers, 2016.).

Uspješna spajanja vode menadžeri koji dijele svoju viziju nove organizacije i stavljaju svoj osobni otisak na upravljanje ljudima. Kako ne bi došlo do neuspjeha u spajanja i preuzimanju menadžment poduzeća treba posvetiti dovoljno vremena upravljanju poslovanja, imati liderske sposobnosti, usmjeriti pozornost na čimbenike uspjeha, stvoriti osjećaj ljudske svrhe i smjera te modelirati željeno ponašanje (Appelbaum, 2007.).

Razlike u stilu upravljanja između poduzeća koja sudjeluju u procesu spajanja i preuzimanja mogu imati negativan utjecaj na uspješnost tog procesa.U postupku preuzimanja, značajan aspekt je spajanje različitih upravljačkih skupina. Općenito, ukoliko menadžment poduzeća preuzimatelja nameće svoj vlastiti stil menadžmentu stečenog poduzeća, može doći do gubitka identiteta menadžmenta poduzećamete i zauzvrat, anksioznosti, nepovjerenja i sukoba, koji može kulminirati "zastojem spajanja/ preuzimanja", što posljedično utječe na pad produktivnosti i loš učinak nakon preuzimanja (Mirc, 2007.).

\subsection{Integracijski problemi}

Ova kategorija uključuje faktore neuspjeha koji su povezani sa problemima integracije. Kao što je već spomenuto, integracija se odnosi na spajanje dva odvojena poduzeća u jedno poduzeće. Integracija je složena, i stoga se poteškoće u vezi s integracijom mogu pojaviti u više oblika. Čimbenici neuspjeha obuhvaćeni ovom kategorijom su loša integracija zadataka, slaba brzina integracije i loš proces integracije (Houwers, 2016.).

Integracija nakon spajanja i preuzimanja ključna je za uspjeh navedenih procesa.. Integriranje
Wittine, Z., Bedeković, H., Filipović, D.

Utjecaj korporativne kulture na uspješnost spajanja i preuzimanja 
Wittine, Z., Bedeković, H., Filipović, D.

Utjecaj korporativne kulture na uspješnost spajanja i preuzimanja nakon spajanja i preuzimanja uključuje provedbu promjena u funkcionalnim aktivnostima, organizacijskim strukturama i korporativnim kulturama dva poduzeća kako bi se njihova konsolidacija ubrzala i kako bi postali funkcionalna cjelina (Koi-Akrofi, 2016.).

Proces integracije odnosi se na cijeli proces spajanja i preuzimanja, od planiranja integracije do implementacije. Ovaj proces uključuje postupak dubinske analize, kao i upravljanja cjelokupnom tranzicijom. Razumljivo je da će, ako je proces integracije nesavršen, nepovoljno utjecati na ishod stjecanja (Houwers, 2016.). Većina neuspjeha događa se tijekom integracije nakon transakcije. Spajanja i preuzimanja ne uspijevaju stvoriti značajnu vrijednost, nego uništavaju vrijednost poteškoćama koje nastaju nakon transakcije (Preuss, 2018.).

Neuspjeh preuzimanja uslijed loše integracije zadataka rezultat je, kako je već navedeno, dva različita sustava u poduzećima koji se ne podudaraju. Slaba brzina integracije odnosi na brzinu kojom bi se integracija trebala odvijati. Neki istraživači tvrde da bi se integracija trebala odvijati maksimalnom brzinom, dok drugi smatraju da bi prebrza integracija zapravo mogla uništiti vrijednost. Ti različiti pogledi u pogledu brzine integracije ilustriraju odnos između brzine integracije i uspješnosti preuzimanja (Uzelac, 2015.).

\section{Utjecaj korporativne kulture na uspješnost integracijskih procesa}

Korporativna kultura sastavni je dio organizacije i zapravo je "kultura organizaciji ono što je osobnost za pojedinca" (Lodorfos i Boateng, 2006.). Kao takva, korporativna kultura igra značajnu ulogu kada je u pitanju uspjeh transakcija povezanih sa spajanjem i preuzimanjem.

lako kulturna kompatibilnost ne jamči uspjeh spajanja i preuzimanja, menadžeri je ipak preferiraju više od kulturne heterogenosti, jer zajedničko iskustvo i kultura čine temelj povjerenja (Lodorfos i Boateng, 2006.). Drugim riječima, kulturna sličnost stoga služi kao sila koja okuplja članove poduzeća koja su sudjelovala u spajanju i preuzimanju te stvara osjećaj kohezije i posljedično utječe na postizanje sinergije. Stoga bi prepreke ili nekompatibilnosti u kulturi mogle biti velike prepreke za očekivani dobitak od spajanja i preuzimanja (Lodorfos i Boateng, 2006.).

Dakle, korporativna kultura ima utjecaj na to koliku će vrijednost dva poduzeća kreirati u procesu spajanja i preuzimanja. Istraživanja su pokazala da poduzeća koja imaju kompatibilnu korporativnu kulturu djeluju bolje u spajanjima i preuzimanjima te da je upravljanje kulturnim razlikama u transakcijama spajanja i preuzimanja ključni dio integracijskih procesa (Preuss, 2018.). Ako su korporativne kulture preuzimatelja i poduzeća-mete slične, tj. ako postoji sličnost u načinu obavljanja poslova kao i u procesu donošenja odluka i ponašanja zaposlenika smanjuje se mogućnost konflikata, što za posljedicu ima veću vjerojatnost uspješnog poslovanja nakon preuzimanja (Filipović, 2012.).

Što se tiče kulturnih razlika postoje dva suprotna stajališta. Jedni sugeriraju da kulturne razlike mogu stvoriti velike prepreke za postizanje koristi od integracijskih procesa, odnosno mogu narušiti protok informacija, ometati prijenos znanja i negativno utjecati na opstanak poduzeća (Lodorfos i Boateng, 2006.). Dok drugi tvrde da razlike u kulturi između poduzeća koja se spajaju mogu biti izvor stvaranja vrijednosti i učenja (Stahl, Günter i Voigt, 2008.).

Kulturne razlike također se smatraju izvorom manje predanosti radu, što otežava suradnju. Također, povećano gubljenje ključnih zaposlenika ciljanog poduzeća utječe na uspješnost poslovanja. Dodatno, nedostatak suradnje proizlazi iz "mi" nasuprot "njima" stava, što dovodi do neprijateljstva između zaposlenika dvaju poduzeća (Mirc, 2007.). Ukoliko dva poduzeća ne djeluju kao jedno, šanse za uspjeh su im minimalne jer će im se osim internih problema, pojaviti i oni eksterni poput loše usluge za kupce proizvoda ili korisnike usluga, obeshrabreni investitori i negativne slika u medijima (Sherman, 2010.). Također, percepcija kulturnih razlika utječe na bogatstvo dioničara tako što utječe na očekivanja investitora o budućim rezultatima ciljanog poduzeća (Stahl, Günter i Voigt, 2008.). Ako se kulturne razlike ne otkriju tijekom dubinske analize i ne budu uključene u uvjete dogovora, obično će doći do razočaranja povratom investicije. Primarni razlog zbog kojeg ovo pitanje može utjecati na 
vrijednost dogovora je da kulturne razlike, kao što je već napisano, dovode do niže produktivnosti, što vodi nižim prihodima i zaradi, te stoga nova organizacija može vrijediti manje od očekivanog. Kao rezultat korporativnih razlika, često je pametno konzervativno procijeniti zaradu i novčani tok u prvoj godini nakon transakcije (Sherman, 2010.).

Kulturne razlike mogu poboljšati konkurentsku prednost poduzeća pružanjem pristupa jedinstvenim i potencijalno vrijednim mogućnostima i resursima. Ipak, nisu sve vrste kulturnih razlika podjednako vrijedne. Kulturne razlike svojstvene prekograničnim spajanjima i preuzimanjima vjerojatno će biti povezane s višim razinama komplementarnosti sposobnosti i većim mogućnostima učenja od onih svojstvenih domaćim spajanjima i preuzimanjima (Stahl, Günter i Voigt, 2008.).

Međutim, prednosti spajanja i preuzimanja mogu se ostvariti samo ako kulturne razlike između kompanija koje se spajaju nisu toliko velike da ometaju uspješan prijenos sposobnosti, dijeljenje resursa i učenje. Primjerice, ako su stilovi najviših menadžerskih timova dijametralno suprotstavljeni jedni drugima, a članovi organizacije ne dijele ključne vrijednosti, malo je vjerojatno da bi ciljano poduzeće moglo dodati vrijedne strateške sposobnosti koje preuzimatelj može iskoristiti. To se događa jer kulturna distanca povećava vjerojatnost da su stilovi upravljanja, organizacijske prakse, i sl. spojivi te uzrokuje probleme u provedbi integracijskog procesa. Kulturne će razlike najvjerojatnije dovesti do komplementarnih sposobnosti koje se međusobno uklapaju i poboljšavaju samo kad su kulturne razlike umjereno velike (Stahl, Günter i Voigt, 2008.).Stoga, treba izbjegavati transakcije u kojima je korporativna kultura preuzimatelja dijametralno suprotna od one kod poduzeća-mete. Također, u situaciji kada su korporativne kulture znatno različite, korporativna kultura poduzeća-mete se mijenja nakon preuzimanja prema preferencijama preuzimatelja (Filipović, 2012.).

Tijekom spajanja i preuzimanja, nerijetko dolazi do negativne reakcije zaposlenika na te procese koji se često se nazivaju "kulturni sukob” ili "sudar kultura”. Pokazalo se da kulturni sukob ima disfunkcionalne posljedice poput niže predanosti radu, smanjene suradnje među zaposlenicima, gubitak velikog broja stečenih zaposlenika, posebice menadžera, te posljedično pad bogatstva dioničara poduzeća preuzimatelja i pogoršanje operativnih performansi poduzeća-mete (Lodorfos i Boateng, 2006.). Stoga, iznimno je važno na pravi način pristupiti integracijskim izazovima, kako naposljetku ne bi došlo do neželjenih posljedica zbog loše ljudske integracije ili integracije zadataka.

Nekompatibilnost korporativnih kultura javlja se kao pojačivač kulturnih organizacijskih sukoba koji mogu negativno utjecati na pojedinca i organizacijsku uspješnost zbog sprječavanja materijalizacije suradnje. Kulturološki su sukobi izraženiji u prekograničnim u odnosu na domaće transakcije, jer takva spajanja i preuzimanja integriraju ne samo dvije kompanije koje imaju različite organizacijske kulture, već nacionalne raznolikosti ukorijenjene u organizacijskoj kulturi (Mirc, 2007.).

Važno je napomenuti da su korporativne i nacionalna kultura, također, povezane međusobno. Korporativnu kulturu dijelom određuju okolno društvo, osobni vrijednosni prioriteti članova organizacije te priroda primarnih zadataka organizacije. Organizacije su i same članice društva i stoga s kolektivom dijele određene vrijednosti nacionalne kulture. Također, izložene su društvenom pritisku da se, barem djelomično, usklade s vrijednostima nacionalne kulture (Dauber, 2012.).

Nadalje, korporativna kultura vrijedna je korporativna imovina i stoga se očekuje se da poduzeća sa jakom korporativnom kulturom, razviju politike spajanja i preuzimanja koje čuvaju ili povećavaju vrijednost tih kultura (Bargeron, Kenneth i Smith, 2012.)

Istraživanje je pokazalo da relativna veličina preuzimanja koju su napravila poduzeća s jakom korporativnom kulturom čine otprilike jednu trećinu takvih transakcija napravljenih od strane drugih poduzeća. Povrati koje ostvaruje preuzimatelj i promjena zajedničke ukupne vrijednosti preuzimanja i poduzeća-mete uglavnom su znatno niži u velikim preuzimanjima koje su napravila poduzeća s jakim korporativnim kulturama nego u velikim akvizicijama koje su napravila druga poduzeća. Navedeno sugerira da tržište očekuje
Wittine, Z., Bedeković, H., Filipović, D.

Utjecaj korporativne kulture na uspješnost spajanja i preuzimanja 
Wittine, Z., Bedeković, H., Filipović, D.

Utjecaj korporativne kulture na uspješnost spajanja i preuzimanja veće uništenje vrijednosti kad poduzeća sa snažnom kulturom ostvaraju velike transakcije preuzimanja u usporedbi s drugim poduzećima. Također, poduzeća sa snažnim korporativnim kulturama koja ulaze u velika preuzimanja trpe veće propadanje svoje kulture, nego takva poduzeća koje ne ulaze u velike akvizicije (Bargeron, Kenneth i Smith, 2012.).

Korporativna kultura ne utječe na učestalost stjecanja. Poduzeća s jakom kulturom češće stječu manje tvrtke, što je u skladu s perspektivom da proces spajanja i preuzimanja može poremetiti redovno poslovanje i korporativnu kulturu, a manje ponude je lakše apsorbirati. Također, vjerojatno je da poduzeća $s$ jakom kulturom neće steći slična poduzeća, što je u skladu s gledištem da je kultura prenosivo bogatstvo. Poduzeća s jakom kulturom koja ostvaruju velika preuzimanja vjerojatno će izgubiti svoju snažnu kulturu za razliku od onih poduzeća koje se suzdrže od takvih poslova. Također, kako je već spomenuto, poduzeća s jakom kulturom pokazuju prinose slične onima koje imaju poduzeća bez jakih kultura, ali ti su prinosi znatno niži ako je uzorak ograničen na velika preuzimanja, isto u skladu s gledištem da se integracijom remeti vrijedna korporativna kultura (Bouwman, 2013.).

Nova kultura mora učinkovito povezati ljudske resurse kombinirane organizacije sa poslovnim strategijama nove organizacije (Shearer, Hames i Runge, 2001.). Usredotočenost na zaposlenike i menadžerska strategija za upravljanje kulturnim razlikama vrijedan su faktor u transakcijama spajanja i preuzimanja koji mogu podržati proces integracije nakon zaključenja sporazuma (Preuss, 2018.).

Motivacija zaposlenika je presudan čimbenik za uspjeh spajanja i preuzimanja te igra ključnu ulogu u suočavanju s osjećajima zaposlenika tijekom organizacijske promjene. Ako je zaposlenik motiviran i zadovoljene su njegove osnovne potrebe, fiziološke i sigurnost, tada su zaposlenici motiviraniji za postizanje ciljeva. Dakle, uspjeh se uvelike postiže kad i ako su motivirani zaposlenici. Međutim, organizacijske promjene stvaraju stres, tjeskobu, strah i depresiju s kojima će se zaposlenici i organizacije morati suočavati u vremenu nakon provedbe transakcije (Spriggs, 2018.).

Preuzimanja poduzeća sa sobom nose povećane kontrole nad zaposlenicima preuzetog poduzeća, a zaposlenici to doživljavaju kao ograničavanje njihove slobode (Filipović, 2012.). Stoga, posebno je važan stupanj autonomije koji je dopušten članovima poduzeća koja se spajaju za uspjeh same integracije. Kolaborativna je strategija namijenjena iskorištavanju zajedničkog znanja i resursa temeljenih na zadržavanjem „najboljeg iz oba svijeta" i s posebnim naglaskom na povećanu autonomiju zaposlenika, što dodatno motivira zaposlenike te je pokretačka snaga za uspješnu integraciju (Mirc, 2007.). Dakle, ukoliko poduzeća motiviraju svoje zaposlenike, učine da se oni osjećaju dijelom novonastalog poduzeća, ne mijenjaju naglo korporativnu kulturu i radne običaje na koje su navikli zaposlenici poduzeće-mete, veća je vjerojatnost da ljudski faktor neće negativno utjecati na uspješnost spajanja i preuzimanja.

Uspjeh same integracije, ovisi i o menadžerima, jer su spajanja i preuzimanja većim dijelom vođena od strane visokih i srednjih menadžera, gdje uspjeh posljedično ovisi o stupnju njihovog znanja, vještine i liderskih sposobnosti (Dunbar, 2014.). Stoga, kako je već naglašeno, iznimno je važno imati iskusan menadžerski tim u procesu spajanja i preuzimanja jer nedostatak iskustva i nekompetentnost menadžera poduzeća može biti jedan od razloga neuspjeha integracijskih procesa. Također, jedan od važnih menadžerskih izazova, kako je spomenuto u prijašnjem poglavlju, je upravljanje razlikama u korporativnim kulturama poduzeća. U situaciji kada je poduzeće-mete preuzeto zbog lošeg poslovanja neophodno je promijeniti korporativnu kulturu kako bi poduzeće-meta nakon preuzimanja krenulo u pravom smjeru. U tom slučaju, u poduzećumeti također može postojati nezadovoljstvo trenutnim stanjem u poduzeću i veća spremnost prihvaćanju neophodnih promjena (Filipović, 2012.). Ali, menadžeri rijetko kad imaju koherentnu i proaktivnu strategiju za optimizaciju prednosti spajanja dviju kultura zajedno ili za rješavanje kulturoloških problemima u slučajevima spajanja i preuzimanja. Štoviše, čak i u slučajevima gdje postoje definirane strategije i planovi, menadžeri rijetko pregledavaju te planove u različitim fazama procesa integracije što dovodi do ogromnih problema neposredno nakon provođenja procesa spajanja i preuzimanja (Lodorfos i Boateng, 2006.). Također, ona poduzeća u kojoj menadžeri pružaju 
manje pažnje procjeni kulturne razlike tijekom faze prije spajanja, također će posvetiti manje pažnje tome u fazi nakon spajanja i suočiti će se s više problema međukulturalnog upravljanja nakon spajanja te posljedično postići niži uspjeh integracijskog procesa (Weber i Tarba, 2012.).

Korporativna kultura, iako je izuzetno otporna na promjene, doista se može promijeniti odgovarajućim planom komunikacije. Svaki je proces promjene teško proći, međutim, strateški povećavajući količinu i način pružanja informacija mogu se značajno povećati šanse za uspjeh. Svako spajanje i preuzimanje oglašeno je kao vrlo stresno za pojedinca.Pokazalo se kako treba biti empatičniji prema žrtvama u situaciji i pružiti im sve potrebne i valjane, objektivne informacije koje mogu značajno smanjiti njihov stres i povećati njihovu učinkovitost na radu. Stoga je komunikacija ključna varijabla za postizanje učinkovitije organizacije i uspješnijeg postupka spajanja i preuzimanja (Appelbaum, 2007.). Radikalne promjene korporativne kulture u poduzećima koja su preuzeta, kao i izostanak asimilacije kultura poduzeća koja se spajaju, često uzrokuju neuspjeh kod spajanja i preuzimanja (Filipović, 2012.).

I zato, glavni je cilj integracije korporativne kulture sprječavanje nepotrebnih sukoba i otpora prihvaćanju nove organizacije. Komunikacija, i vertikalna i horizontalna, kako je navedeno iznad, smatra se jednim od ključnih čimbenika uspjeha. Kad situacija eskalira, mogu se pojaviti slučajevi gdje novi suradnici nisu u mogućnosti skladno surađivati i naći rješenje. Različite navike rješavanja problema mogu izazvati nepotrebne sukobe. Glavni negativni rezultati toga uvjeti su smanjenje produktivnosti, frustracija radnika i smanjenje zadovoljstva poslom. Ako ova situacija traje duže, postoji potreba za radikalnim promjenama među protivnicima nove korporativne kulture. Važno je pretpostaviti da ljudi ne vole promjene i inovacije te da su nisu skloni odbaciti skepticizam prilikom planiranja procesa integracije (Kazik, 2012.).

Upravljanje kulturnim razlikama nije faktor koji određuje ishod spajanja i preuzimanja, ali njegovu korisnost svakako ne treba zanemariti, budući da igra važnu ulogu u postizanju novih sinergija (Remanda, 2016.). Realizacija očekivane sinergije, kako je napisano u prethodnom poglavlju, jedan je od najznačajnijih izazova u procesu spajanja i preuzimanja jer je to ključni cilj za ulazak poduzeća u integracijski proces. Dakle, upravljanje kulturnim razlikama utječe ne samo na integracijske i menadžerske izazove, već i na izazove povezane s realizacijom očekivane sinergije.

Kada se govori o kulturnoj integraciji, bitno je u obzir uzeti dva aspekta, a to su akulturacija i kulturna tolerancija. Akulturacija zaposlenika je način uklanjanja nastalih sukoba, odnosno uklanjanje kulturnih razlika. Slijedeći smjer u kojem se obje organizacije odluče ići, akulturacija će se oblikovati na tri različita načina: bilo asimilacijom, gdje dominantna kultura preuzimatelja vrši visoku razinu promjene na apsorbiranom poduzeću; ili dvije kulture koegzistiraju bez međusobne kontrole i dvije organizacije prolaze kroz istu umjerenu razinu miješanja; ili kad su ove dvije kulture toliko integrirane da se operativne koristi preuzimatelja ne mijenjaju značajno u ciljanom poduzeću (Remanda, 2016.).

lako poduzeća znaju da je kulturna integracija od vitalnog značaja za postizanje uspjeha, dvije trećine njih i dalje nemaju specifičan pristup procjeni i integraciji korporativnih kultura u procesu spajanja i preuzimanja (Bouwman, 2013.).

Kako bi poduzeće osiguralo da korporativna kultura ne utječe negativno na uspjeh spajanja i preuzimanja potrebno je dopustiti da kulturne razlike igraju ulogu prilikom određivanja vrijednosti transakcije, shvatiti da su korporativne kulture oba poduzeća važne, priznati da nije u interesu ijednog poduzeća da održava obje kulture (osim u slučaju da će preuzeto poduzeće nastaviti biti autonomno, i tad su kulturne razlike neznačajne za uspjeh spajanja i preuzimanja) te smisliti na koji način spojiti dvije kulture kako ne bi uništile transakciju (Sherman, 2010.).

\section{Zaključak}

Spajanja i preuzimanja služe za provedbu razvojne strategije poduzeća i kao odgovor na tržišne podražaje čine poduzeća konkurentnijima, omogućuju brzi rast poduzeća, povećavaju efikasnost i ostvaruju vrijednost za dioničare i ostale investitore. Tijekom procesa spajanja i preuzimanja poduzeća se susreću s brojnim izazovima koji nisu neovisni jedan o drugom te
Wittine, Z., Bedeković, H., Filipović, D.

Utjecaj korporativne kulture na uspješnost spajanja i preuzimanja 
Wittine, Z., Bedeković, H., Filipović, D.

Utjecaj korporativne kulture na uspješnost spajanja i preuzimanja je potrebno prevladati kombinaciju izazova kako bi se ostvarila korist u vidu postizanja očekivanih sinergija. Ukoliko poduzeća zanemare i ne posvete se rješavanju navedenih izazova, najčešće dolazi do neuspjeha integracijskih procesa. Naime, pokazalo se da čak do 80 posto spajanja i preuzimanja ne ispunjavaju očekivanja i ciljeve određene prije ulaska u integracijski proces. Uspješnost spajanja i preuzimanja uvelike ovisi o korporativnoj kulturi, a ipak je kultura nerijetko zanemarena u samom procesu. Korporativna kultura je sastavni dio organizacije, odnosno kultura je organizaciji ono što je osobnost za pojedinca. Problem s procjenom utjecaja korporativne kulture na uspješnost spajanja i preuzimanja je u tome što rijetko koje poduzeće javno dijeli informacije 0 svojoj korporativnoj kulturi. Stoga je za provedbu primarnog istraživanja potrebno doći do zaposlenika i menadžera poduzeća preuzimatelja ili poduzeća-mete. Samim time, primarna su istraživanja podložna mogućim subjektivnim mišljenjima osoba uključenih u integracijski proces. Osim toga, s obzirom na složenost korporativne kulture teško je odrediti njene determinante te kvantificirati njihov utjecaj na uspješnost spajanja i preuzimanjima. Stoga se u istraživačkim radovima najčešće generalno promatra utjecaj korporativne kulture na uspješnost spajanja i preuzimanja.
Korporativna je kultura vrijedna korporativna imovina te se očekuje da poduzeća $s$ jakom kulturom ulaze u proces spajanja i preuzimanja s politikom očuvanja ili povećanja vrijednosti te kulture. Ipak, procesi spajanja i preuzimanja remete redovno poslovanje i korporativnu kulturu, stoga tržište očekuje veće uništenje vrijednosti kod poduzeća sa snažnom korporativnom kulturnom, posebice u velikim transakcijama. Korporativna kultura utječe na to koliku će vrijednost dva poduzeća kreirati u procesu spajanja i preuzimanja. Ostvarenje predviđene sinergije ključan je razlog za ulazak poduzeća u integracijske procese, pa je stoga realizacija očekivane sinergije jedan je od najznačajnijih izazova u procesu spajanja i preuzimanja. Ukoliko su korporativne kulture preuzimatelja i poduzeća-mete slične, veća je vjerojatnost ostvarenja očekivanih sinergija te uspješnog poslovanja nakon preuzimanja. Ako postoje kulturne razlike one mogu biti velika prepreka uspjehu integracijskih procesa jer narušavaju protok informacija, ometaju prijenos znanja, dovode do manje predanosti radu, a posljedično dovode do nezadovoljstva i otpora zaposlenika te negativnog utjecaja na poslovanje poduzeća. Dakle, ukoliko se ne premoste integraciijski izazovi, posebice oni povezani $s$ ljudskom integracijom, malo je vjerojatno da ce

Slika 2. Međuodnos ključnih izazova i rješenja prilikom integracijskih procesa s aspekta korporativne kulture

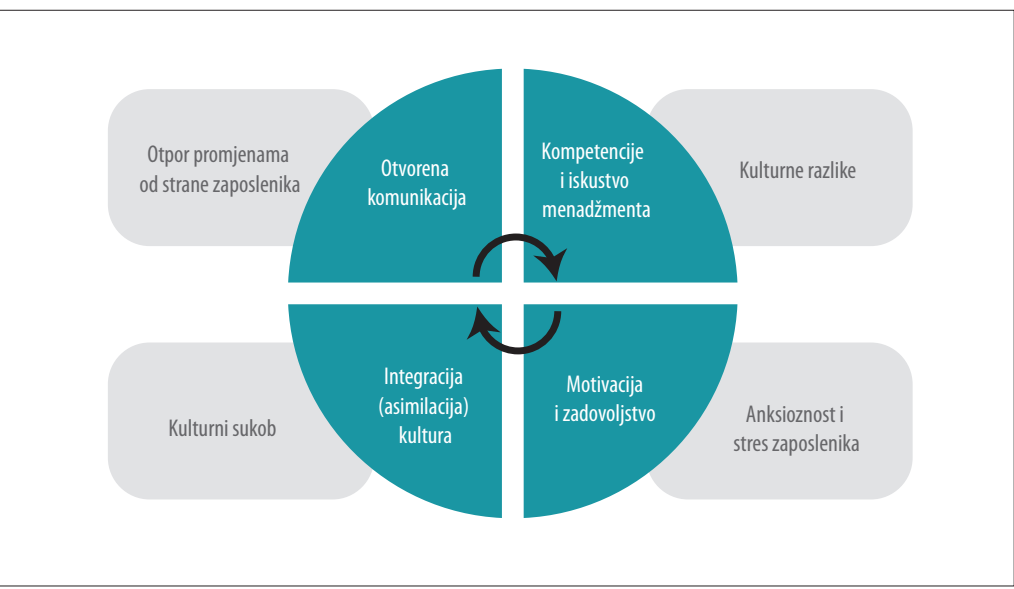

Izvor: izrada autora. 
se ostvariti željene sinergije. Suprotno stajalište smatra da razlike u korporativnoj kulturi mogu biti izvor stvaranja vrijednosti i učenja. Međutim, bitno je naglasiti da se prednosti spajanja i preuzimanja mogu ostvariti samo ako kulturne razlike između poduzeća koja se spajaju nisu toliko velike da ometaju uspješan prijenos vještina te dijeljenje resursa i učenja. Dakle, treba izbjegavati situacije u kojima je korporativna kultura preuzimatelja u potpunosti različita od one kod poduzećamete.Tijekom procesa spajanja i preuzimanja nerijetko dolazi do negativne reakcije zaposlenika koja se naziva kulturni sukob ili sudar kultura. Kulturni sukob dovodi do niže predanosti radu, smanjene suradnje među zaposlenicima, gubitka velikog broja ključnih zaposlenika, izostanke $s$ radnog mjesta, a posljedično i do pada bogatstva dioničara te negativnog utjecaja na poslovanje oba poduzeća. Zato je iznimno je važno na pravi način pristupiti integracijskim izazovima, kako naposljetku ne bi došlo do neželjenih posljedica zbog loše ljudske integracije ili integracije zadataka. Pravovremenom kulturnom integracijom sprječavaju se nepotrebni sukobi i opor prihvaćanju nove organizacije. Izostanak asimilacije kultura, se uz radikalne promjene korporativne kulture, navodi kao najččšci uzrok neuspjeha kod spajanja i preuzimanja. Motivacija zaposlenika ključan je faktor za uspjeh spajanja i preuzimanja. Motivirani zaposlenik je produktivniji te manje otporan na promjene. Organizacijske promjene često rezultiraju anksioznošću i stresom zaposlenika, što ima za posljedicu nižu produktivnost i smanjenje zadovoljstva poslom. Kako ne bi došlo do toga, bitna je komunikacija sa zaposlenicima te pravovremeno pružanje svih potrebnih, važnih i objektivnih informacija. Ukoliko poduzeća motiviraju zaposlenike i učine in zadovoljnima, te ukoliko ne mijenjaju naglo korporativnu kulturu i radne običaje na koju su navikli zaposlenici poduzeća-mete, veća je vjerojatnost da ljudski faktor neće negativno utjecati na uspješnost spajanja i preuzimanja. Menadžeri preferiraju kulturnu homogenost, jer iako ne jamči uspjeh spajanja i preuzimanja, ipak pozitivno utječe na navedene procese, dok kulturna heterogenost stvara tenzije i najčešce ima negativan utjecaj na uspješnost. Važno je imati iskusan menadžerski tim u procesu spajanja i preuzimanja jer nedostatak iskustva i nekompetentnost menadžera može biti jedan od razloga neuspjeha integracijskih procesa. Upravljanje razlikama u korporativnim kulturama poduzeća predstavlja izazov za menadžere. Ipak, menadžeri rijetko kada imaju planiranu strategiju za optimizaciju prednosti spajaju dviju korporativnih kultura zajedno ili za rješavanje kulturoloških problema u slučajevima. Čak i ako postoji takva strategija, menadžeri je rijetko pregledavaju što dovodi do ogromnih problema u fazi integracije preuzetog poduzeća, kada je utjecaj korporativne kulture posebno bitan. Dakle, poduzeća, iako su svjesna da je korporativna kultura i kulturna integracija od vitalnog značenja za uspjeh spajanja i preuzimanja, nemaju specifičan pristup procjeni i strategiju za integraciju kultura, što bi se u budućnosti moralo promijeniti ukoliko poduzeća žele uspješno poslovati nakon spajanja i preuzimanja te ostvariti ciljeve i sinergije. Također, kako korporativna kultura ne bi igrala ulogu u neuspjehu spajanja i preuzimanja nužno je naći rješenja za probleme s kojima se poduzeća susreću pri procesu spajanja i preuzimanja. Prije svega, potrebno je shvatiti da zaposlenici ne vole promjene, vide in kao prijetnju te će najvjerojatnije pružiti otpor prema promjenama. Kako bi se to spriječilo, bitno je pravovremeno i otvoreno komunicirati sve informacije vezane uz proces spajanja i preuzimanja, te sama komunikacija mora biti usmjerena na dijalog, a ne na monolog. Također, potrebno je uključiti kulturne razlike prilikom određivanja vrijednosti transakcije, jer korporativna kultura može uvelike utjecati na realizaciju očekivanih sinergija. Naposljetku, korporativne kulture oba poduzeća su važne te bi konačna kultura trebala sadržavati temeljne vrijednosti oba poduzeća.
Wittine, Z., Bedeković, H., Filipović, D.

Utjecaj korporativne kulture na uspješnost spajanja i preuzimanja 
Wittine, Z., Bedeković, H., Filipović, D.

Utjecaj korporativne kulture na uspješnost spajanja i preuzimanja

\section{Literatura}

Appelbaum, S. H., Gandell, J., Shapiro, B. T., Belisle, P., Hoeven, E. (2000) Anatomy of a merger: behavior of organizational factors and processes throughout the pre-during-post-stages (part 2).Management Decision, 38(10): 674-684.

Bahtijarević Šiber, F., Borović, S., Buble, M., Dujanić, M., Kapustić, S. (1991) Organizacijska teorija. Zagreb:Informator.

Bargeron, L., Kenneth, L. Smith, J. (2012) Corporate culture and M\&A acitivity. University of Pitttsburgh.

Bouwman, C. H. S. (2013) The role of corporate culture in mergers and acquisitions. Etinne Perrault (ed.), NOVA Science Publishers.

Buble, M., Cingula, M., Dujanić, M., Dulčić, Ž., Gonan Božac, M., Galetić, L., Ljubić, F., Pfeifer, S., Tipurić, D. (2005) Strateški menadžment.Zagreb: Sinergija.

Dauber, D. (2012) Opposing positions in M\&A research: culture, integration and performance. Cross Cultural Management, 19(3): 375-398.

DePamphilis, D.M. (2010) Mergers, acquisitions and other restructuring activities. 2. izdanje. San Diego: Academic Press.

DiGeorgio, R. (2002) Making mergers and acquisitions work: What we know and don't know-Part II. Journal of Change Management, 3(3): 259-274.

Dunbar, J. K. (2014) The role of organizational leadership capability in mergers \& acquisitions. Dissertation Abstracts International Section A: Humanities and Social Sciences, 74(12-A)(E).

Filipović, D. (2012) Izazovi integracijskih procesa.Zagreb: Sinergija.

Galetić, L. (2011) Organizacija velikih poduzeća.Zagreb: Sinergija.

Gunkel, M., Schlaegel, C., Rossteutscher, T., Wolff, B. (2015) The human aspect of cross-border acquisition outcomes: The role of management practices, employee emotions, and national culture. International Business Review, 24(3): 394-408.

Houwers, R. (2016) M\&A Failure Factors. Diplomski rad. Enschede, Netherlands: University of Twente.

Kazik, R. (2012) The impact of the corporate culture on the success or the failure of mergers and acquisition, Journal of Economic Literature (JEL), 60-70.

Koi-Akrofi,G.(2016) Mergers and acquisitions failure rates and perspectives on why they fail. International Journal of Innovation and Applied Studies, 17: 150-158.

Lodorfos, G., Boateng, A. (2006) The role of culture in the merger and acquisition process: Evidence from the European chemical industry. Management Decision, 44(10): 1405-1421.

Mallak, L. (2001) Understanding and changing your organisations's culture. Industrial Management,42(2): 18-25.

Marks, K. H., Howard, J. A. (2015) Optimizing Private Middle-Market Companies for M\&A and Growth. Advances in Mergers and Acquisitions: 67-82. Emerald Group Publishing Limited.

Mirc, N. (2007) Mergers and Acquisitions: revisiting the human factor in the light of a knowledge-based view of the firm and complexity theory. EIASM, 22nd workshop on Strategic Human Resource Management. France.

Nguyen, H., Kleiner, B. H. (2003) The effective management of mergers. Leadership \& Organization Development Journal, 24(8): 447-454.

Pablo A. L., Javidan, M. (2009) Mergers and acquisitions: Creating integrative knowledge. John Wiley \& Sons.

Pavičić, J., Alfirević, N., Aleksić, Lj. (2006) Marketing i menadžment u kulturi i umjetnosti. Zagreb: 
Masmedia d.o.0.

Peters, T., Waterman, R. H. (2008) U potrazi za izvrsnošću, Profil, Zagreb.

Petit, B. S., Ferris, K.R. (2013) Valuation for Mergers and Acquisition. 2nd Edition. FT Press.

Preuss, B. (2018) Influence of organizational culture on M\&A performance: Evidence from European firms. Doktorski rad: How important is culture in shaping economic behaviour? Copenhagen Business School, Denmark.

Price, J. (2013) Misvaluation: Another explanation for the failure of corporate acquisitions. Corporate Ownership \& Control, 11(1):777-788.

Rana, S., Jayasooriya, I., Nikolova, N. (2010) The role of corporate culture in mergers and acquisitions - the case of Swedbank. Završni rad. School of Sustainable Development of Society and Technology. Malardalen University. Sweden.

Remanda, L. S. (2016) A review of organizational culture in the mergers and acquisitions process. Journal of Media Critiques (JMC), 99-110.

Schein, E. H. (2004) Organisational culture and leadership. 3. izdanje. San Francisco: Jossey-Bass.

Shearer, C. S., Hames, D. S., Runge, J. B. (2001) How CEOs influence organizational culture following acquisitions. Leadership \& Organization Development Journal, 22(3): 105-113.

Sherman,A.J.(2010) Mergers and acquistions from A to Z.4. izd. SAD: American Management Association.

Shusta,A. (1999) Are you paying too much for that acquisition?. Harvard Business Review, 77(6): 190-190.

Sikavica, P., Novak, M. (1993) Poslovna organizacija. 2. izdanje.Zagreb: Informator.

Smirchich, L. (1983) Concepts of culture and organizational analysis. Administrative Science Quarterly, 28(3): 339-358.

Stahl, Günter, K., Voigt, A. (2008) Do cultural differences matter in mergers and acquisitions? A tentative model and examination. Organization Science, 19(1): 160-176.

Škuflić, L., Šokčević, S. (2016) Učinci preuzimanja i spajanja u hrvatskom gospodarstvu. International scientific conference: Knowledge based sustainable economic development, Beograd, 97-106.

Tipurić, D. i sur. (2008) Korporativno upravljanje.Zagreb: Sinergija.

Uzelac, B., Bauer, F., Matzler, K., Waschak, M. (2015) The moderating effects of decision-making preferences on M\&A integration speed and performance. The International Journal of Human Resource Management: $1-27$.

Weber, Y., Tarba, S. Y. (2012) Mergers and acquisitions process: The use of corporate culture analysis. Cross Cultural Management, 19(3): 288-303.

Žugaj, M., Cingula, M. (1992) Temelji organizacije. Varaždin: Foing.

Williams, A., Dobson, P., Walters, M. (1993) Changing culture: New organizational approaches (developing strategies). 2. izdanje. London: Chartered Institute of Personnel and Development. 
